Bangladesh J. Plant Taxon. 15(1): 1-12, 2008 (June)

(C) 2008 Bangladesh Association of Plant Taxonomists

\title{
STRUCTURE AND COMPOSITION OF UNDERSTORY PLANT ASSEMBLAGES OF SIX LAND USE TYPES IN THE LORE LINDU NATIONAL PARK, CENTRAL SULAWESI, INDONESIA
}

\author{
RAMAdHANIL $^{1}$, SRI Soetarmi TJitrosoedirdjo ${ }^{2}$ ANd Dede SETIAdI ${ }^{2}$ \\ Department of Biology, Faculty of Mathematics and Natural Sciences, \\ Herbarium Celebense (CEB), Tadulako University, Kampus Bumi Tadulako Palu, \\ Central Sulawesi 94118, Palu, Indonesia
}

Keywords: Cacao plantation, Primary forest, Structure and Composition, Understory plant assemblages

\begin{abstract}
In the present study the diversity and species composition of understory plants are examined in the submontane forest of Lore Lindu National Park, Central Sulawesi, Indonesia by comparing three rain forest types and three types of plantations of cacao differing in use intensity. The results showed that 376 understory plant species consisting of 140 species of tree seedlings, 162 herbs and shrubs, 29 terrestrial ferns and 45 climbers were collected in all land use types. The mean species numbers of herbs did not differ among three forest types but was significantly higher in cacao plantation with high use intensity, being about three times higher than in undisturbed rain forest and lightly disturbed rain forest. Urticaceae, Araceae, Hypoxidaceae and Acanthaceae were predominant in the forests, whereas Asteraceae and Poaceae in the cacao plantations. The number of species of ferns and climbers did not differ between forests and plantations. The study also recorded several invasive plant species at the cacao plantations such as Piper aduncum L., Bidens pilosa L., Ageratum conyzoides L., Sclerea purpuriens Steud and Paspalum conjugatum Berg.
\end{abstract}

\section{Introduction}

Tropical rain forests are among the most species rich places on earth (Jacobs 1988). Many studies demonstrated high tree diversity of tropical rain forests (Proctor et al.1983, Kochummen et al. 1990, Phillips et al. 1994, Wright et al. 1997, Hamann et al. 1999, Kessler et al. 2005), especially economically important trees (Whitmore 1990). However, the studies on understory assemblages (Gentry and Dodson 1987), herbs, shrubs, lianas, and epiphytes (Laska 1997, Svenning 2000, Gradstein et al. 2005) are limited. Ecologically, understory plant species assemblages play a fundamental role in diversity, structure, and functional aspects of tropical forests (Svenning 2000). They may show different patterns of diversity than tree species due to different responses to light level, nutrient availability, and temperature (Laska 1997, Svenning 2000, Siebert 2002).

\footnotetext{
${ }^{1}$ Corresponding author. E-mail: pitopang_64@yahoo.com

${ }^{2}$ Department of Biology, Faculty of Mathematics and Natural Sciences, Bogor Agricultural University, Kampus Dermaga Raya Bogor, Indonesia.
} 
Similar to other plant groups, data on understorey plant assemblages of Sulawesi, Indonesia are still limited and published data on the effects of habitat modification on such plant assemblages in the island are missing. This study, therefore, makes an attempt to address the question how the floristic composition, diversity, richness and density of understorey plant communities differ between three rain forest types and three cacao plantations types with different use intensity in submontane forest of Lore Lindu National Park, Central Sulawesi, Indonesia.

\section{Materials and Methods}

The study area was located in the surroundings of Toro, a village at the western

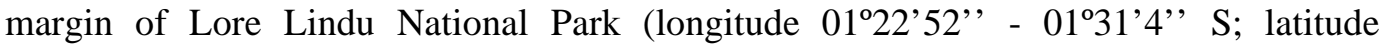
$120^{\circ} 1$ '37'" - 120'3'5', E) about $100 \mathrm{~km}$ south of Palu, the Capital of Central Sulawesi, Indonesia. Research was carried out from April 2004 to December 2005. Detailed information on climate and soil conditions of this part of Central Sulawesi is not yet available (see Whitten et al. 1987). Falk et al. (2005), however, reported that mean annual rainfall in the study area varied between $1,500 \mathrm{~mm}$ and 3,000 $\mathrm{mm}$, mean relative humidity $85.17 \%$, and monthly mean temperature $23.40^{\circ} \mathrm{C}$. The margin of the National Park is characterized in many parts by a mosaic of primary forest, primary less disturbed forest, primary more disturbed forest, secondary forests, and several land-use systems with cacao, coffee, maize and rice as the dominating crops (Gerold et al. 2004). The elevation of the selected sites is between $800 \mathrm{~m}$ and $1100 \mathrm{~m}$, therefore belongs to the submontane forest zone (Whitten et al. 1987).

Understory plants were sampled in six different land use types differing in use intensity, including three types of rain forest and three types of agroforestry system, as follows:

1. Land use types A-C: Rain Forest

Land use type A (“Wana”): low use intensity / undisturbed rain forest. Natural forest with traditional use only; human activities restricted to collecting of medicinal plants and extensive hunting; rattan palms abundantly present.

Land use type B ("Pangale 1"): medium use intensity / lightly disturbed rain forest. Natural forest with rattan extraction, rattan palm removed.

Land use type C ("Pangale 2"): medium use intensity / moderately disturbed rain forest. Selectively logged forest, containing small to medium sized gaps, disturbance of ground vegetation, and increased abundance of lianas following the selective removal of canopy trees and rattan. 


\section{Land use types D-F: Agroforestry System}

Land use type D (“Pahawa pongko 1"): moderate use intensity. Cacao forest garden with natural shade trees (= remaining forest cover) in the forest margin.

Land use type E ("Pahawa pongko 2"): light use intensity. Cacao cultivated under mixed canopy planted shade trees in the forest margin.

Land use type F (“Huma”): high use intensity. Cacao cultivated under canopy of monospecific planted shade trees more distant from the forest margin.

For each land use type, four replicates were selected. At all sites understory vascular plants (including herbs, tree seedlings, ferns and climbers) less than $1.50 \mathrm{~m}$ high were sampled in ten $2 \times 2 \mathrm{~m}$ subplots. Plots were selected similar to plots for tree diversity study. Plots of land use types A-C were located at slightly higher elevation (hill-tops) than land use types D-F (lower slopes).

All recognizable morphospecies of understory plants were collected. Plant collection was according to the "Schweinfurth method" (Bridson and Forman 1999). Additionally, fertile voucher specimens were collected for identification. Processing of the specimens was conducted at the Herbarium Celebense (CEB), Universitas of Tadulako, Palu, Indonesia. Identification was done in the field, in the CEB, in Herbarium Bogoriense (BO), Indonesia, and in National Herbarium of Netherland (L), Leiden. Vouchers were deposited in CEB, with duplicates in BO, L, Herbarium Gottingen, Germany, and Herbarium Biotrop Bogor, Indonesia.

\section{Statistical analyses}

Relative density, relative biomass, relative frequency and Importance Value Indices (IVI) were calculated according to the formulae of Dumbois-Muller and Ellenberg (Soerianegara and Indrawan 1998, Setiadi et al. 2001).

i) Relative density $(\%)=$ (No. of individuals of a family or species / Total no. of individuals in sample) $\times 100$

ii) Relative biomass $(\%)=($ Biomass of a species or family / Total biomass in sample $) \times$ 100

iii) Relative frequency $(\%)=$ (Sampling units containing a species/ Sum of all frequencies) $\times 100$

iv) IVI for a species is the sum of its relative density, relative biomass, and relative frequency.

Additionally, we compared the taxonomic and structural composition between the land use types. Taxonomic composition was quantified on a family basis by calculating 
the family relative density, relative diversity, relative dominance, and Family Importance Value (FIV) indices according to the formulae of Mori et al. (1983):

i) Family relative density $(\%)=($ No. of trees in a family / Total no. of trees $) \times 100$

ii) Family relative diversity $(\%)=$ (No. of species in a family / total number of species) $\times 100$

iii) Family relative dominance $(\%)=($ Total basal area for all trees in a family $/$ Total basal area of all families) $\times 100$

iv) FIV is the sum of family relative diversity, relative density, and relative dominance.

The presence and absence data were used to calculate species similarity among all plots by application of Sörensen's similarity coefficient:

$$
\mathrm{S}=2 \mathrm{C}(\mathrm{A}+\mathrm{B})^{-1}
$$

where A is the number of IV (important value) in Stage 1, B is the number of IV in Stage 2 , and $\mathrm{C}$ is the number of IV common to both stages. Furthermore, dissimilarity index (1 - Sörensen similarity coefficient) among those plots where then clustered by using Biodiv 97 (Meßner 1996) and the program Statistica 5.5. Dissimilarity values were used to calculate a two-dimensional ordination of all samples using multidimensional scaling.

The program SYSTAT version 7.0 was used to perform statistical analyses. Arithmetic means are given \pm 1 standard deviation (SD). ANOVA was of a one-way type. Tukey's Honest Significant Different Test was used for multiple comparisons of means.

\section{Results and Discussion}

\section{Species richness}

In total, 376 understory plant species consist of 140 species of tree seedlings, 162 herbs and shrubs, 29 terrestrial ferns and 45 climbers were collected in all land use types. Statistically, the mean species number of herbs did not differ among three forest types but was significantly higher in cacao plantation type $\mathrm{F}$ (high use intensity of cacao plantation) compared to all other five land use types (Fig. 1). The mean species number of herbs in cacao plantation type F $(35.3 \pm 5.8)$ was about three times higher than in undisturbed and lightly disturbed rain forests.

In contrast, the mean number of species of tree seedlings was highest in moderately disturbed rain forest (type C: $36.5 \pm 3.0$ ), followed by rain forest of light use intensity and undisturbed rain forest, with the mean numbers of species being $25.5 \pm 3.4$ and 25.3 \pm 5.3 , respectively. The lowest number of tree seedling species $(4.5 \pm 3.7)$ was in the land use type $\mathrm{F}$ (high use intensity of cacao plantation). 


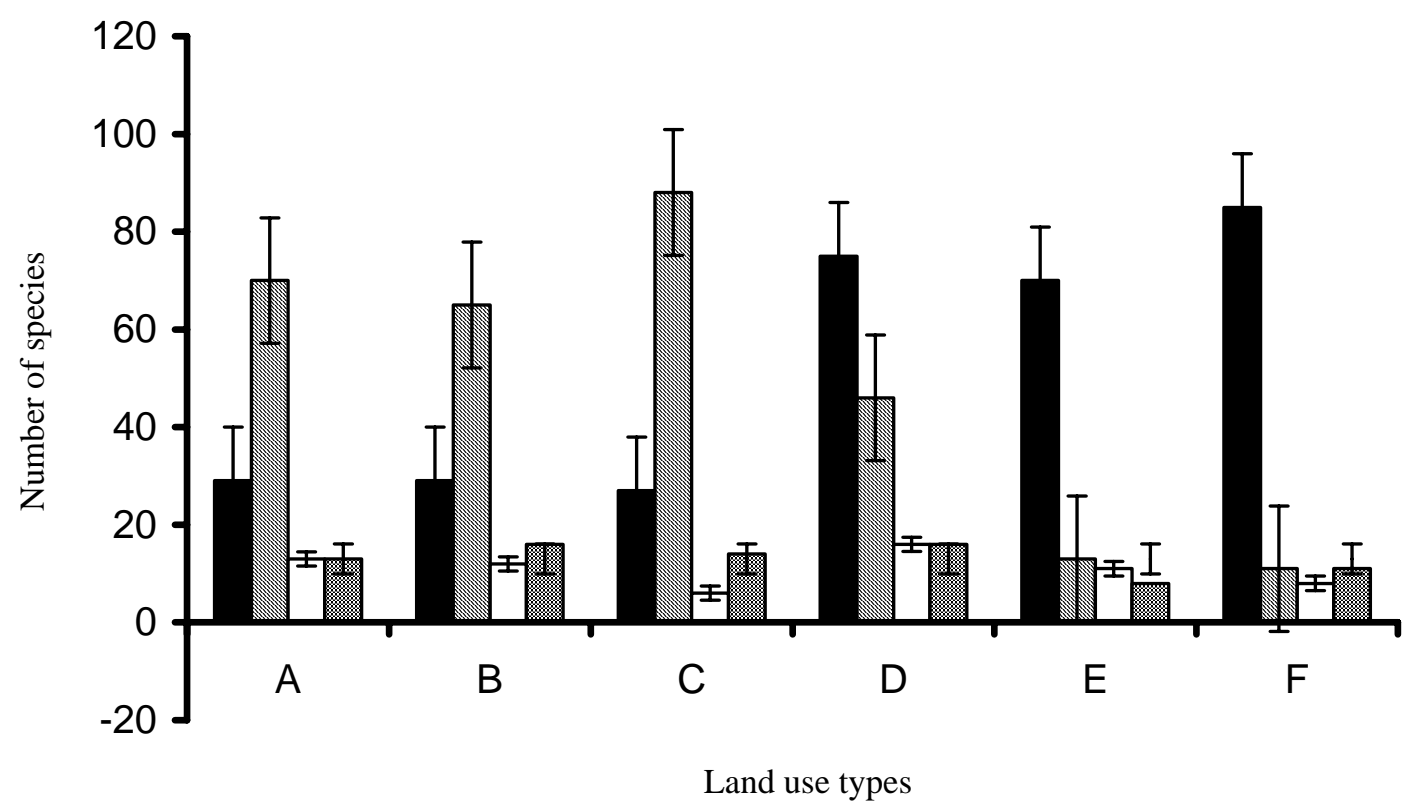

DHerbs \& shrubs

$\square$ Seedlings

口Ferns

—Lianas

Fig. 1. Species richness ( \pm standard deviation) of understory plants (herbs \& shrubs, seedlings, ferns and liana) in six land use types at the Lore Lindu National Park, Indonesia. A = undisturbed rain forest, $\mathrm{B}=$ lightly disturbed rain forest, $\mathrm{C}=$ moderately disturbed rain forest, $\mathrm{D}=$ moderate use intensity of cacao plantation, $\mathrm{E}=$ light use intensity of cacao plantation and $\mathrm{F}=$ high use intensity of cacao plantation.

\section{Taxonomic composition}

The species composition of understory plants was different among land use types. In the undisturbed forest (type A), dominating tree seedling species were Acer laurinum Hassk. (Aceraceae), Areca vestiaria Giseke (Arecaceae), Calophylum soulattri Burm.f. (Clusiaceae), Aglaia argentea Bl. (Meliaceae), Ardisia celebica Scheff. (Myrsinaceae). Syzigium accuminatisimum Miq. (Myrtaceae), Lasianthus sp. (Rubiaceae) Meliosma sumatrana (Jack.) Walp (Sabiaceae), Palaquium quercifollium (de Vriese) Burck (Sapotaceae). Herb and shrub species were presented by Alpinia galanga (L.) Swartz., Costus speciosus (Koen.) J.E. Smith, Elletaria sp. (Zingiberaceae), four unidentified species of Elatostema spp. and Pauzolzia zeylanica Benn. (Urticaceae). Ferns were mostly represented by Christella dentata Forst (Thelypteridaceae), Cyathea amboinensis (Aldew.) Merr. (Cyatheaceae), Davalia trichomanoides Bl. (Davaliaceae), Diplazium crenatoserratum (Bl.) Moore (Athryriaceae), Nephrolepis bisserata (Sw.) Schott and Selaginella sp. (Selaginellaceae), whereas liana and vine species were four juvenile endemic rattans, namely Calamus inops Becc. ex Heyne, Calamus minahassae Becc., Calamus ornatus Blume ex Schult. var. celebicus Becc., and Calamus zollingerii Becc. (Arecaceae), an endemic scrambler bamboo Dinochloa barbata S. Dransfield (Poaceae), 
Freycenetia angustifolia Bl. (Pandanaceae), Stephania japonica (Thunb. ex Murr.) Miers (Menispermaceae), and Ziziphus angustifolius (Miq.) Hatus. (Rhamnaceae).

In the lightly disturbed rain forest (type B), dominant tree seedling recorded were Areca vestiaria, Arenga pinnata (Wurmb) Merr., Pinanga aurantiaca Mogea (Arecaceae), Callophyllum soulattri (Clusiaceae), Leea indica (Burm.f.) Merr. (Leeaceae), Pandanus sarasinorum Lauterb (Pandanaceae), Meliosma sumatrana (Jack) Walp (Sabiaceae), Palaquium quercofollium (Giff.) Engler and Chionanthus laxiflorus Blume (Oleaceae). Whereas herb species recorded were Staurogyne elongata (Blume) Kuntze (Acanthaceae), Curculigo orchioides Gaertn. (Amaryllidaceae), Homalomena humilis (Jack) Hook.f. (Araceae), Begonia aptera Bl. (Begoniaceae), Elatostema cf. macrophylla, Elatostema sp. 1, Elatostema sp. 2 (Urticaceae), Spathyphyllum canaefollium Schott (Araceae) and Tacca palmata Bl. (Taccaceae). There were only two juvenile rattans species, namely Calamus zollingerii and Calamus minahassae, but the other common lianas species were Ziziphus angustifolius (Rhamnaceae), Alyxia celebica D.J. Middleton (Apocynaceae), Medinilla sp. (Melastomataceae), Gnetum cuspidatum Bl. (Gnetaceae) and Centrosema sp. (Fabaceae). Christella dentata, Diplazium esculentum (Retz.) Sw., Cyathea amboinensis, Nephrolevis biserrata and Helminthostachys zeylanica (L.) Hook. (Ophioglosaceae) were the co-dominant fern species in this land use type.

The herb species in moderate use intensity forest (type C) were mostly presented by Elatostema sp. 2 (Urticaceae), Homalomena humilis (Araceae), Curculigo orchioides (Amarylidaceae), Elatostema sp. 1, Elatostema sp. 3 and Tacca palmata. There were only six species of ferns in this habitat and again we recorded Lindsaea lucida, Christella dentata, Cyathea sp. and Helmintostachys zeylanica as seedlings. The dominant liana seedlings were Stephania japonica (Menispermaceae), Dinochloa barbata L. (Poaceae), Arcangalesia flava (L.) Merr. (Menispermaceae), Piper miniatum L. (Piperaceae), Calamus inops and an endemic rattan Korthalsia celebica Becc. (both Arecaceae).

The understory plants species composition was significantly different between cacao plantations and forests. The number of native species of forest climbers and herbs decreased in land use types D, E and F, where they were replaced by the weedy herb species. Although there were Elatostema sp. 1 (Urticaceae), Tacca palmata (Taccaceae), Elatostema sp. 2, Curculigo orchioides and Impatiens platypetala Lindl. (Balsaminaceae), all typical for the herb layer of the forest, we collected a large number weedy species in land use type D such as Ageratum conyzoides (Asteraceae), Elephantopus mollis L. (Asteraceae), Crassocephalum crepidiodes (Benth.) S. Moore (Asteraceae), Paspalum conyugatum, Setaria palmifolia (J. Koenig) Stapf, Panicum repens L., Eragrostis tennella (L.) Beauv. ex R. \& S. (Poaceae), Cyathula prostata (L.) Bl. (Amaranthaceae), Coleus sp. (Lamiaceae), Hyptis capitata Jacq. (Lamiaceae), Commelina diffusa Burm.f., Pollia secundiflora (Bl.) Bakh.f. (Commelinaceae), Blumea 
lacera (Burm.f.) DC. (Asteraceae), and Scleria purpurascens Steud. In land use types E and $\mathrm{F}$, the herb species layer was entirely composed of the weedy species.

At the family level, the understory plant composition was different among six land use types (Table 1). Urticaceae was dominant in land use types A, C and D, but Taccaceae in B. Whereas Poaceae was dominant family in land use type $\mathrm{E}$ and Asteraceae in $\mathrm{F}$.

\section{Similarity of understory plant assemblages}

The result of similarity analyses of understory plant assemblages among the six land use types showed that there was a high degree of similarity percentage among land use types A, B and C. The value of similarity between A vs B was $67 \%$, A vs C was $63 \%$ and between $\mathrm{B}$ and $\mathrm{C}$ was $67 \%$. On the other hand, the taxonomic composition between land use types E and F also showed a high degree of similarity, with a Sörensen index 0.82. Similarity percentages of understory plant between forests and cacao plantations showed low values of Sörensen index. The value of similarity between A vs D was $28 \%$, A vs E was $9 \%$, and between $\mathrm{A}$ and $\mathrm{F}$ was $7 \%$, whereas between $\mathrm{B}$ vs $\mathrm{D}, \mathrm{E}$ and $\mathrm{F}$ were $34 \%$, $14 \%$ and $10 \%$, respectively.

The cluster analysis and two dimensional scaling based on Sörensen indices for all possible pair wise combinations of understory plant species assemblages showed a clear separation between the three types of forests and the cacao plantation types (Figs 2 and 3 ). There is a high degree of overlapping between land use types A (natural forest) and B (lightly undisturbed forest). The cacao forest garden (type D) represented a relatively distinct group. Both land use types E (cacao cultivated under mixed canopy of shade tree) and F (cacao cultivated under monospecific canopy of shade tree) showed a high degree of overlapping.

The richness and composition of understory plant species are presumably due to their different responses to abiotic factors such as differential light levels, nutrient availability, water availability, wind and temperature (Marquis et al. 1986, Denslow 1987, Laska 1997, Svenning 2000, Siebert 2002). The abundance and diversity of understory plants

are also influenced by biotic factors. For example, birds, mammals and bats are known to be important dispersers of pioneer and forest climax tree species, shrub, herb and epiphytic species (Galindo-Gonzales et al. 2000, Siebert 2002). In the present study, herbs showed highest species richness in cacao cultivated forest gardens (type F), which is in accordance with the findings of Siebert (2002). The higher light levels and more open canopy in this land use type may explain the observations. 
Table 1. The ten main understory plant families under each of six land use types based upon family important value (FIV). $A=$ undisturbed rain forest, $B=$ lightly disturbed rain forest, $C=$ moderately disturbed rain forest, $D=$ moderate use intensity of cacao plantation, $E=$ light use intensity of cacao plantation, and $\mathrm{F}=$ high use intensity of cacao plantation.

\begin{tabular}{|c|c|c|c|c|c|c|c|c|c|c|c|c|}
\hline \multirow[t]{3}{*}{ No. } & \multicolumn{12}{|c|}{ Land Use Types } \\
\hline & \multicolumn{2}{|l|}{ A } & \multicolumn{2}{|l|}{ B } & \multicolumn{2}{|l|}{$\mathrm{C}$} & \multicolumn{2}{|l|}{$\mathrm{D}$} & \multicolumn{2}{|l|}{$E$} & \multicolumn{2}{|l|}{$\mathrm{F}$} \\
\hline & Families & FIV & Families & FIV & Families & FIV & Families & FIV & Families & FIV & Families & FIV \\
\hline 1 & Urticaceae & 92.80 & Taccaceae & 24.35 & Urticaceae & 106.60 & Urticaceae & 72.84 & Poaceae & 89.84 & Asteraceae & 86.95 \\
\hline 2 & Araceae & 55.50 & Acanthaceae & 20.96 & Araceae & 62.92 & Poaceae & 54.29 & Asteraceae & 56.13 & Poaceae & 80.74 \\
\hline 3 & Hypoxidaceae & 40.10 & Urticaceae & 17.42 & Hypoxidaceae & 35.49 & Asteraceae & 39.10 & Acanthaceae & 29.31 & Caryophyllaceae & 29.26 \\
\hline 4 & Acanthaceae & 14.60 & Araceae & 16.16 & Taccaceae & 16.98 & Araceae & 21.60 & Lamiaceae & 22.00 & Amaranthaceae & 13.33 \\
\hline 5 & Zingiberaceae & 7.48 & Hypoxidaceae & 14.38 & Gesneriaceae & 15.26 & Taccaceae & 18.60 & Caryophyllaceae & 16.73 & Lamiaceae & 12.53 \\
\hline 6 & Gesneriaceae & 7.22 & Gesneriaceae & 4.83 & Acanthaceae & 13.41 & Lamiaceae & 17.42 & Rubiaceae & 11.74 & Сyperaceae & 11.18 \\
\hline 7 & Orchidaceae & 5.52 & Zingiberaceae & 2.91 & Zingiberaceae & 13.17 & Hypoxidaceae & 13.31 & Cyperaceae & 10.24 & Urticaceae & 8.07 \\
\hline 8 & Commelinaceae & 2.68 & Orchidaceae & 2.75 & Balsaminaceae & 9.54 & Balsaminaceae & 10.88 & Urticaceae & 9.03 & Commelinaceae & 7.69 \\
\hline 9 & Araliaceae & 2.30 & Begoniaceae & 2.35 & Maranthaceae & 8.39 & Acanthaceae & 8.05 & Malvaceae & 8.97 & Euphorbiaceae & 6.62 \\
\hline \multirow[t]{3}{*}{10} & Taccaceae & 2.05 & Balsaminaceae & 1.16 & Commelinaceae & 6.84 & Comelinaceae & 7.73 & Verbenaceae & 8.10 & Rubiaceae & 5.25 \\
\hline & $\begin{array}{l}\text { Remaining } \\
\text { families }\end{array}$ & 69.80 & $\begin{array}{l}\text { Remaining } \\
\text { families }\end{array}$ & 192.75 & $\begin{array}{l}\text { Remaining } \\
\text { families }\end{array}$ & 11.41 & $\begin{array}{l}\text { Remaining } \\
\text { families }\end{array}$ & 36.18 & $\begin{array}{l}\text { Remaining } \\
\text { families }\end{array}$ & 37.91 & $\begin{array}{l}\text { Remaining } \\
\text { families }\end{array}$ & 38.38 \\
\hline & Total & 300 & Total & 300 & Total & 300 & Total & 300 & Total & 300 & Total & 300 \\
\hline
\end{tabular}




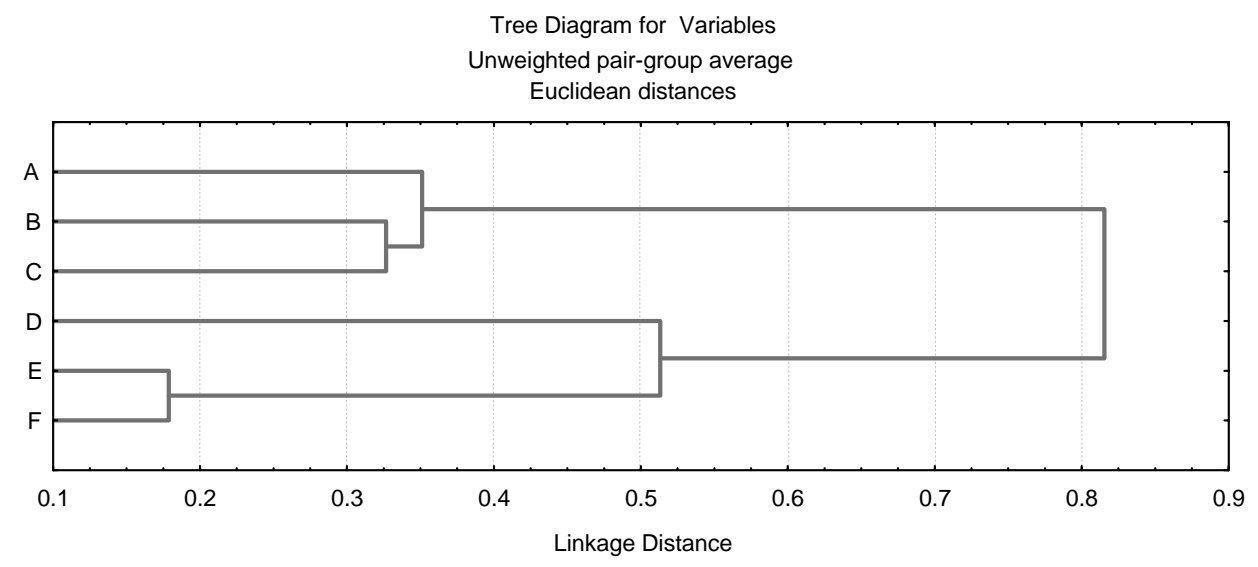

Fig. 2. Dendrogram of cluster analysis of understory assemblages based on dissimilarity index (1 - Sörensen similarity indices) among six land use types differing in use intensity. $\mathrm{A}=$ undisturbed rain forest, $\mathrm{B}=$ lightly disturbed rain forest, $\mathrm{C}=$ moderately disturbed rain forest, $\mathrm{D}=$ moderate use intensity of cacao plantation, $\mathrm{E}=$ light use intensity of cacao plantation, and $\mathrm{F}=$ high use intensity of cacao plantation.

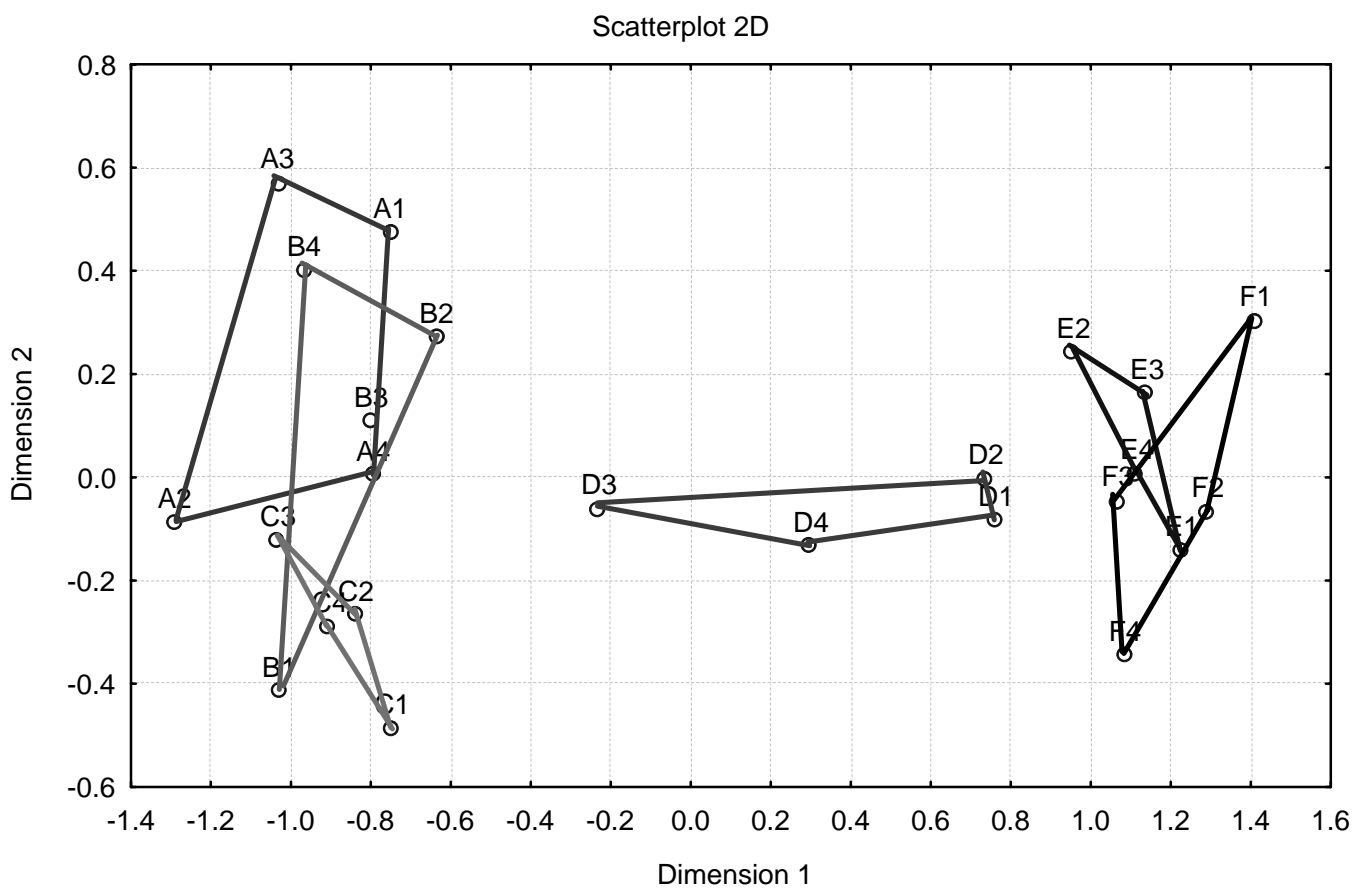

Fig. 3. Two dimensional scaling of understory species assemblages similarity based on Sörensen indices in the six land use types. Sites belonging to the same habitat type are connected by lines. $\mathrm{A}=$ undisturbed rain forest, $\mathrm{B}=$ lightly disturbed rain forest, $\mathrm{C}=$ moderately disturbed rain forest, $\mathrm{D}=$ moderate use intensity of cacao plantation, $\mathrm{E}=$ light use intensity of cacao plantation, and $\mathrm{F}$ = high use intensity of cacao plantation. 
The cacao forest garden, known as a traditional forest farming system (Siebert 2002), is an important land use type in the margins of Lore Lindu National Park. The high species diversity and complex structure of traditional forest farming systems maintain many of the ecosystem functions and processes found in primary forests. These include low ground-level light intensities, low transpiration rates of understory plants, reduced wind speed, diurnal temperature and humidity fluctuations, large and continuous organic matter inputs, efficient nutrient cycling, and a diverse habitat for forest flora and fauna (Perfecto et al. 1996, Beer et al. 1998, Siebert 2002). Traditional forest farming system may also provide connectivity between isolated primary forest fragments (GalindoGonzales et al. 2000).

In this study, a mix of native and exotic weed species was recorded in the cacao forest garden (type D). The composition of herbs in this forest type agrees with the results of Siebert (2002) who found both native and exotic weed species occurring in traditional forest farming systems. At the family level, Asteraceae and Poaceae were the dominant families of exotic weeds in cacao plantation areas. Probably, the invasion by species of these two families is due to the excellent dispersal capacities of their species.

Interestingly, the dominant tree seedling species in three cacao plantation types was Piper aduncum (Piperaceae), with important value indices more than 75\%. Weber (2003) stated that Piper aduncum is one of invasive alien species widely distributed in the tropics including Malesia, Polynesia and Melanesia. Tjitrosoedirdjo (2005) who inventoried the invasive alien species in Indonesia pointed out that this species is originally from South America but it has recently invaded some islands in Indonesia including Sulawesi.

Despite the differing levels of disturbance, the three forest types (A, B and C) showed significant similarities among themselves suggesting resilience of the occupying species towards disturbance. On the other hand, although the overall species assemblages of types E (light use intensity) and F (high use intensity) were similar, type D (moderate use intensity) remained different from them probably due to the presence of high tree seedlings and weedy species.

\section{Acknowledgements}

This study was carried out in the framework of interdisciplinary research programme "Stability of Rain Forest Margins in Indonesia" (STORMA) funded by the German Research Foundation (DFG-SFB 552) and the Directorate General of Higher Education Department of National Education Republic of Indonesia. We gratefully acknowledge logistic support from STORMA's Indonesia partner universities in Bogor and Palu, Institut Pertanian Bogor, Universitas Tadulako (UNTAD), the Ministry of Education in Jakarta (DIKTI), the authorities of Lore Lindu National Park "Balai Taman Nasional Lore Lindu” and the Nature Conservancy Indonesia. Great appreciation and gratitude to 
Dr. H. Sahabuddin Mustafa, MS (Rector of Tadulako University), Dr. H. Arifuddin Bidin (Head of Research Center of Tadulako University), Prof. S.R. Gradstein and M. Kessler (both Georg August University of Gottingen Germany) for their constructive comments. I would like to thank the PITA group of National Herbarium of Netherlands Leiden, Herbarium Bogoriense staff, Herbarium Celebense staff, the people of Ngata Toro and to the Lore Lindu National Perk authority for their many kind of support. The manuscript profited from the comments by an anonymous reviewer.

\section{References}

Beer, J., Muschler, R., Kass, D. and Somarriba, E. 1998. Shade management in coffee and cacao plantations. Agroforestry Systems 38: 139-164.

Bridson, D. and Forman, L. 1999. The Herbarium Handbook. 3rd ed., Royal Botanic Gardens, Kew, pp. 1334.

Denslow, J.S. 1987. Tropical rain forest gaps and tree species diversity. Annu. Rev. Ecol. Syst. 18: 431-451.

Falk, U., Ibrom, A., Oltchev, A., Kreilein, H., June, T., Rauf, A., Merklein, J. and Gravenhorst, G. 2005. Energy and water fluxes above a cacao agroforestry system in Central Sulawesi Indonesia, indicate effects of land use change on local climate. Met Zeitsch. 14: 219-225

Galindo-Gonzales, J., Guevara, S. and Sosa, V. 2000. Bat- and bird-generated seed rains at isolated trees in pastures in a tropical rainforest. Conservation Biology 14: 1693-1703.

Gentry, A.H. and Dodson, G. 1987. Contribution of nontrees to species richness of a tropical rain forest. Biotropica 19: 149-156.

Gerold, G., Fremerey, M. and Guhardja, E. (eds.) 2004. Land Use, Nature Conservation and the Stability of Rainforest Margins in South Asia. Springer - Verlag Berlin Heidelberg, Germany, pp. 1-533.

Gradstein, S.R., Tan, B., King, C., Zhu, R.L., Drubert, C. and Pitopang, R. 2005. Catalogue of the Bryophytes of Sulawesi, Indonesia. Journal of Hattori Botanical Laboratory 98: 213-257.

Hamann, A., Barbon, E.B., Curio, E. and Madulid, D.A. 1999. A botanical inventory of a submontane tropical rainforest on Negros Island, Philippines. Biodiversity and Conservation 8: 1017-1031.

Jacobs, M. 1988. The Tropical Rainforests: A first encounter. Springer-Verlag. Berlin, pp. 1-295.

Kessler, M., Keßler, P.J.A., Gradstein, S.R., Bach, K., Schmull, M. and Pitopang, R. 2005. Tree diversity in primary forest and different land use systems in Central Sulawesi, Indonesia. Biodiversity and Conservation 14: 547-560.

Kochummen, K.M., Lafrankie, J.V. and Manokaran, N. 1990. Floristic Composition of Pasoh Forest Reserve, a Lowland rain forest in Peninsular Malaysia. J. Trop. For. Sci. 3: 1-13.

Laska, M.S. 1997. Structure of understorey shrub assemblages in adjacent secondary forest and old growth tropical wet forests, Costa Rica. Biotropica 29: 29-37.

Marquis, R.J., Young, H.J. and Braker, H.E. 1986. The influence of Understory Vegetation cover on germination and seedling establishment in a tropical lowland wet forest. Biotropica 18: 273-278.

Meßner, S. 1996. Untersuchungen zur Biodiversität der Myrmecofauna (Formicidae) im Parc National de la Como’e (Elfenbeinküste). Diploma Thesis, University of Würzburg, Würzburg, Germany.

Mori, S.A., Boom, B.M., Carvalino, A.M. and Santos, D. 1983. The ecological importance of Myrtaceae in eastern Brazilian wet forest. Biotropica 15: 68-70.

Perfecto, I., Rice, R.A., Greenberg, R.M.E. and van der Vort 1996. Shade coffee: a disappearing refuge for biodiversity. BioScience 46: 598-608. 
Phillips, O.L., Hall, P., Gentry, A.H., Sawyer, S.A. and Vasquez, R. 1994. Dynamic and species richness of tropical rain forest. Proc. Natl. Acad. Sci. U.S.A. 91: 2805-2809.

Proctor, J.J., Anderson, M. and Chai, P. and Vallack, H.W. 1983. Ecological studies in four contrasting lowland rain forest in Gunung Mulu National Park, Serawak. J. Ecol. 71: 237-260.

Setiadi, D., Qoyim, I. and Muhandiono, H. 2001. Penuntun Praktikum Ekologi. Laboratorium Ekologi, Jurusan Biologi, FMIPA, Institut Pertanian Bogor, Indonesia, pp. 1-152.

Siebert, S. 2002. From shade- to sun-grown perennial crops in Sulawesi, Indonesia: implications for biodiversity conservation and soil fertility. Biodiversity and Conservation 11: 1889-1902.

Soerianegara, I. and Indrawan, A. 1998. Ekologi Hutan Indonesia. Laboratorium Ekologi Hutan, Fakultas Kehutanan, Institut Pertanian Bogor, Indonesia, pp. 1-104.

Svenning, J.C. 2000. Small caopy gaps influence plant distribution in the rain forest understory. Biotropica 32: 252-261.

Tjitrosoedirdjo, S.S. 2005. Inventory of the invasive alien plant species in Indonesia. Biotropia 25: 60-73.

Weber, E. 2003. Invasive Plant Species of the World. A Reference Guide to Environmental Weeds. CABI Publishing, CAB International, Wallingford, Oxon, UK.

Whitmore, T.C. 1990. An Introduction to Tropical Rain Forests. Oxford University Press, New York, pp. 1-226.

Whitten, A.J., Mustafa, M. and Henderson, G.S. 1987. The Ecology of Sulawesi, Gadjah Mada University Press, Yogyakarta, pp. 1-777.

Wright, D.D., Jessen, J.H., Burke, P. and de Silva Garza, H.G. 1997. Tree and liana enumeration and diversity on a one-hectare plot in Papua New Guinea. J. Biotropica 29: 250-260.

(Manuscript received on 11 September 2007; revised on 18 November 2007) 